\title{
Correlation between clinical features of systemic lupus erythematosus and levels of antihistone antibodies of the $\operatorname{IgG}, \operatorname{IgA}$, and $\operatorname{IgM}$ isotypes
}

\author{
N R Gompertz, D A Isenberg, B M Turner
}

\begin{abstract}
An attempt was made to define the correlation between the clinical features of systemic lupus erythematosus and levels of circulating antihistone antibodies of the IgG, IgA, and IgM isotypes. Serum antibody levels were determined by enzyme linked immunosorbent assay (ELISA) on serial blood samples $(n=4)$ from 25 patients, representing five subgroups: (a) renal disease; (b) central nervous system disorders; $(c)$ skin and joint disease only; $(d)$ serositis; and $(e)$ deep venous thrombosis with or without spontaneous abortion. The levels of antihistone antibodies of each isotype varied widely from patient to patient, but antibody levels in the four samples from each patient correlated closely. A close correlation between levels of IgG and IgA antihistone antibodies was found but there was no correlation between these isotypes and IgM antihistone antibodies. In individual patients no simple correlation between disease activity and antihistone antibody levels was established, but levels of antihistone antibodies of the IgG and IgA isotypes were significantly higher in those patients in whom the disease was consistently more active.
\end{abstract}

Systemic lupus erythematosus (SLE) is an autoimmune disease characterised by many different clinical features and an apparent diversity of autoantibodies. " Many attempts have been made to correlate the levels of antibodies to various autoantigens with clinical activity in patients with SLE. Most authors agree that antibodies to double stranded DNA fluctuate with disease activity in most patients with the disease, ${ }^{2}$ and there is some evidence that antibodies to poly(adenosine triphosphateribose) also correlate with active disease, ${ }^{3}$ but there is little convincing evidence that other autoantibodies do so. Some autoantibodies, however, are associated with particular clinical features of lupus erythematosus. Thus antiphospholipid antibodies have been described in association with a predisposition to thrombosis, spontaneous abortion, and cerebral disease, ${ }^{45}$ and anti-Ro antibodies with photosensitivity and the neonatal lupus syndrome. ${ }^{6} 7$

Antibodies to mixed histones and individual subfractions are often found in the serum of patients with systemic and drug induced lupus erythematosus. ${ }^{812}$ Some workers have found that up to $83 \%$ of patients with SLE have raised levels of antihistone antibodies ${ }^{12}{ }^{13}$; other studies have reported a much lower incidence. ${ }^{14}$ is The range of reported incidence pre- sumably reflects the variety of methods used for antibody detection, differences in the populations studied, and the fact that some patients have only slightly raised antibody levels, and may or may not be classified as "significantly" increased, depending on the control values used.

Several attempts have been made to relate the levels of antihistone antibodies to clinical features of SLE. Earlier work showed that there were some associations, ${ }^{16}$ but recent results have failed to show a clear relation between levels of antihistone antibodies and the presence or absence of specific symptoms, or the organ systems primarily affected. ${ }^{12}$ is There have been few reports in which the association between disease activity and antihistone antibody levels has been examined in detail, and the available evidence is insufficient to draw general conclusions. ${ }^{11} 1516 \mathrm{~A}$ recent report, however, described a correlation between levels of IgG antibodies to histone fractions and the severity of lupus nephritis. ${ }^{13}$

We have recently shown that serum levels of IgG and IgM antihistone antibodies vary independently in patients with SLE. ${ }^{17}$ In view of this it is important, in examining the relation between antihistone antibodies and disease type or activity, to take account of the isotypes of the antibodies involved. In the present study antihistone antibodies of the $\operatorname{IgG}, \operatorname{IgA}$, and $\operatorname{IgM}$ isotypes were measured in serial blood samples from 25 patients with SLE selected on the basis of well characterised clinical variables and for whom quantitative estimates of disease activity were made when each blood sample was taken.

Patients, materials, and methods

Twenty five patients with SLE were studied. Each met four or more of the revised criteria for the disease, described by the American Rheumatism Association. ${ }^{18}$ Five patients were selected in each of five groups, these being characterised mainly by renal disease, central nervous system (CNS) disorders, joint and skin disease only, serositis, or deep venous thrombosis with or without spontaneous abortion. The criteria for these subgroups have been published elsewhere, ${ }^{19}$ and a disease activity index (UCH/ Middlesex scoring system, scale 1-4) has also been published previously. ${ }^{20}$ This scoring system has been validated recently using a more sophisticated computer based analysis. ${ }^{21}$ Four serial blood samples from each patient were studied "blind". The disease activity index was determined at the time of each bleed. Serum samples obtained from healthy adults served as controls. 
SOLID PHASE IMMUNOASSAY

Histones were purified from human liver and characterised as described previously. ${ }^{17}$ All chemicals were obtained from Sigma Chemical Co. Polystyrene microtitre plates (Dynatech) were coated overnight at $4^{\circ} \mathrm{C}$ with $50 \mu \mathrm{l} /$ well phosphate buffered saline (PBS) containing histone at $10 \mu \mathrm{l} / \mathrm{ml}$. Plates were blocked for one hour with $1 \%$ bovine serum albumin in PBS (PBS/BSA). Human serum, diluted 50,150 , or 450 times in PBS/BSA was added at $50 \mu \mathrm{l} /$ well. After one hour at $4^{\circ} \mathrm{C}$ plates were washed twice with PBS $/ 0 \cdot 1 \%$ Tween-20/1 M NaCl, twice with PBS/0.1\% Tween-20, and once with PBS alone. Peroxidase conjugated goat antibodies to human IgG, IgA, or IgM (Fab ${ }_{2}$ fragments, Sigma), diluted 1000 -fold in blocker, were then added at $50 \mu \mathrm{l} /$ well and the plates incubated for one hour at $4^{\circ} \mathrm{C}$. Use of $\mathrm{Fab}_{2}$ fragments rather than whole antibody provided a useful reduction in background binding. Plates were washed twice in PBS/0.1\% Tween-20 and four times in distilled water before $o$-phenylenediamine dihydrochloride solution $(0.4 \mathrm{mg} / \mathrm{ml}$ in $24 \mathrm{mM}$ citric acid, 51 $\mathrm{mM} \mathrm{Na} \mathrm{HPO}_{4}, 0.012 \% \mathrm{H}_{2} \mathrm{O}_{2}$ (pH 5.0), prepared immediately before use) was added at 100 $\mu \mathrm{l} /$ well. After 10 minutes at room temperature the reaction was terminated with $100 \mu \mathrm{l} /$ well $5 \%$ $\mathrm{H}_{2} \mathrm{SO}_{4}$. Absorbance at $492 \mathrm{~nm}$ was read on a Multiscan II plate reader. The antibody dilutions, times of incubation, and washing protocol described were all established by carrying out test assays in which each variable was changed. The peroxidase reaction was shown to proceed linearly up to absorbance values above those obtained for any of the serum samples in the present series.

\section{Results}

Four serum samples from each of 25 patients were assayed 'blind' for antihistone antibodies of the $\operatorname{IgG}, \operatorname{IgA}$, and $\operatorname{IgM}$ isotypes. Serum samples were assayed at dilutions of 50,150 , and 450 times and in all cases antibody binding increased progressively with decreasing serum dilution. Only in samples with the very highest levels of antibody did binding approach a plateau at a dilution of 50 times. Because of the greater accuracy to be expected from the higher absorbance values obtained with this dilution (generally two to three times greater than at 450) these are the values which are presented in detail. Analysis of results at the three different dilutions led to entirely consistent conclusions.

\section{INDIVIDUAL VARIATION IN ANTIHISTONE}

\section{ANTIBODIES}

Among the serum samples tested, levels of antihistone antibodies of each isotype ranged from one to 16 times the control means. When the coding of the samples was broken and the data inspected it became apparent that this variability resulted primarily from differences among patients, rather than from fluctuations in antibody levels over time in the serum of individual patients. Levels of antihistone antibody in the four serum samples from each patient were generally very similar. This similarity was confirmed by calculating the correlation between pairs of samples from each patient. Thus the correlation coefficients ( $r$ ) obtained by comparing the value for sample 1 with that for sample 3, and the value for sample 2 with that for sample 4 , for each isotype in each patient, were $0.76,0.66$, and 0.72 for $\operatorname{IgG}, \operatorname{IgA}$ and $\operatorname{IgM}$, respectively ( $p<0.001$ in each case). Although noticeable changes in antibody levels occurred in some patients over the sampling period, these changes were not, in themselves, sufficient to account for the variability observed in this patient group. Levels of $\operatorname{IgG}, \operatorname{IgA}$, and IgM antihistone antibodies varied widely among patients but were a relatively constant individual characteristic. Mean values derived from the four samples from each patient are presented in table 1 .

An increase in IgG and IgA antihistone antibodies was common in this patient group, with $21 / 25$ and 20/25, respectively, having mean values more than two standard deviations above the control mean. A similar increase in IgM antihistone antibodies was less common (7/25), largely because of the higher levels found in some members of the control population.

The results in table 1 show that patients with particularly high levels of IgG antihistone antibodies do not, in general, show high levels of IgM antihistone antibodies (Nos 12, 16, and 17). The converse is also true (Nos 14 and 19). Only one patient, No 8, showed a comparable increase in both IgG and IgM antihistone antibodies. In agreement with these observations, there was no correlation between levels of IgG and IgM antihistone antibodies in this patient group, $(r=-0.007)$, confirming our previous conclusion that IgG and IgM antihistone antibody levels vary quite independently in SLE. ${ }^{17}$ In contrast, there was a close correlation between levels of IgG and IgA antihistone antibodies $(r=0.799, p<0.001)$. Despite this correlation some variation in the IgG:IgA ratio was noted (compare patients 5 and 17 in table 1). In a different group of $\mathbf{4 0}$ patients studied previously we also found two in whom IgG and IgA antihistone antibodies were present at widely different levels. ${ }^{17}$

\section{ANTIHISTONE ANTIBODY LEVELS IN \\ SLE SUBGROUPS}

The 25 patients tested were selected to represent five clinical subgroups. ${ }^{19}$ There were no significant differences among these patient subgroups in the levels of $\operatorname{IgG}, \operatorname{IgA}$, or $\operatorname{IgM}$ antihistone antibodies (one way analysis of variance, $F=1 \cdot 32,1 \cdot 06$, and $0 \cdot 39$, respectively, $p \gg 0 \cdot 1$ in each case). The value of this statistical analysis is obviously limited by the wide range of antibody levels and the small number of patients in each group. Results show, however, that the wide variation in the levels of antihistone antibodies cannot be attributed to the existence of different disease subgroups, at least as defined here.

\section{ANTIHISTONE ANTIBODY TITRES AND DISEASE} ACTIVITY

For several patients blood samples were obtained at times of widely differing disease activity. In no case was there any evidence for a correlation 
Table 1: Antihistone antibody levels in systemic lupus erythematosus sera

\begin{tabular}{|c|c|c|c|c|c|c|}
\hline \multirow{2}{*}{$\begin{array}{l}\text { Disease } \\
\text { classification }\end{array}$} & \multirow[t]{2}{*}{ Patient No } & \multicolumn{2}{|c|}{ Disease activity } & \multicolumn{3}{|c|}{ Antihistone antibodyt } \\
\hline & & Sum* & Range & $I g G$ & $\operatorname{IgA}$ & $I g M$ \\
\hline Renal & $\begin{array}{l}1 \\
2 \\
3 \\
4 \\
5\end{array}$ & $\begin{array}{r}8 \\
10 \\
8 \\
10 \\
13\end{array}$ & $\begin{array}{l}(2) \\
(2-3) \\
(1-3) \\
(2-3) \\
(3-4) \\
\text { Mean (SD) }\end{array}$ & $\begin{array}{l}123 \\
466 \\
412 \\
402 \\
561 \\
393(146)\end{array}$ & $\begin{array}{l}209 \\
523 \\
262 \\
211 \\
169 \\
275(143)\end{array}$ & $\begin{array}{ll}438 & \\
266 & \\
348 & \\
303 & \\
199 & \\
311 & (80)\end{array}$ \\
\hline Central nervous system & $\begin{array}{r}6 \\
7 \\
8 \\
9 \\
10\end{array}$ & $\begin{array}{r}11 \\
8 \\
14 \\
9 \\
9\end{array}$ & $\begin{array}{l}(1-4) \\
(1-4) \\
(3-4) \\
(1-4) \\
(1-3) \\
\text { Mean (SD) }\end{array}$ & $\begin{array}{l}454 \\
333 \\
955 \\
456 \\
116 \\
463(276)\end{array}$ & $\begin{array}{l}298 \\
132 \\
619 \\
409 \\
191 \\
330(193)\end{array}$ & $\begin{array}{l}666 \\
334 \\
941 \\
240 \\
230 \\
482(279)\end{array}$ \\
\hline Joint/skin & $\begin{array}{l}11 \\
12 \\
13 \\
14 \\
15\end{array}$ & $\begin{array}{l}4 \\
7 \\
4 \\
4 \\
7\end{array}$ & $\begin{array}{l}(1) \\
(1-2) \\
(1) \\
(1) \\
(1-2) \\
\text { Mean (SD) }\end{array}$ & $\begin{array}{l}96 \\
551 \\
267 \\
274 \\
119 \\
261(162)\end{array}$ & $\begin{array}{l}63 \\
358 \\
214 \\
133 \\
114 \\
176(115)\end{array}$ & $\begin{array}{l}537 \\
284 \\
325 \\
701 \\
430 \\
455(151)\end{array}$ \\
\hline Serositis & $\begin{array}{l}16 \\
17 \\
18 \\
19 \\
20\end{array}$ & $\begin{array}{l}10 \\
11 \\
10 \\
11 \\
10\end{array}$ & $\begin{array}{l}(2-3) \\
(2-3) \\
(2-3) \\
(2-4) \\
(2-3) \\
\text { Mean (SD) }\end{array}$ & $\begin{array}{l}1312 \\
553 \\
325 \\
399 \\
401 \\
598(365)\end{array}$ & $\begin{array}{l}561 \\
464 \\
113 \\
206 \\
258 \\
320(186)\end{array}$ & $\begin{array}{r}241 \\
88 \\
400 \\
1016 \\
286 \\
406(321)\end{array}$ \\
\hline Deep venous thrombosis & $\begin{array}{l}21 \\
22 \\
23 \\
24 \ddagger \\
25 \\
(n=12)\end{array}$ & $\begin{array}{r}8 \\
8 \\
9 \\
-7\end{array}$ & $\begin{array}{l}(2) \\
(2) \\
(2-3) \\
-1-2) \\
\text { Mean (SD) } \\
\text { Mean (SD) }\end{array}$ & $\begin{array}{rr}389 & \\
241 & \\
382 & \\
223 & \\
348 & \\
317 & (71) \\
83 & (20)\end{array}$ & $\begin{aligned} 249 & \\
189 & \\
220 & \\
159 & \\
237 & \\
211 & (37) \\
64 & (45)\end{aligned}$ & $\begin{array}{l}550 \\
257 \\
412 \\
670 \\
346 \\
447(147) \\
211(148)\end{array}$ \\
\hline
\end{tabular}

*Sum of disease activities at each of the four sampling times.

$+\mathrm{A}_{495} \times 10^{3}$. Average of assays on four different serum samples at a dilution of 50 times.

fFor this patient estimates of disease activity were not available for all sampling times.

between levels of antihistone antibody and disease activity. Results from five patients showing the widest ranges of disease activity over the period of sampling are given in table 2 . Although differences in the levels of IgG, IgA, or IgM antihistone antibodies did indeed occur among samples, these were not associated with changes in disease activity, nor were they sufficiently great to account for the variability in the patient population.

The overall severity of SLE varies widely, with some patients having consistently active disease and others milder forms with occasional relapses. To obtain a measure of disease severity

Table 2: Antihistone antibody levels in systemic lupus erythematosus sera taken at times of differing disease activity

\begin{tabular}{llllrr}
\hline $\begin{array}{l}\text { Disease } \\
\text { classification }\end{array}$ & $\begin{array}{l}\text { Patient } \\
\text { No }\end{array}$ & $\begin{array}{l}\text { Disease } \\
\text { activity }\end{array}$ & \multicolumn{3}{c}{ Antihistone antibody } \\
\cline { 4 - 6 } & & & IgG & IgA & IgM \\
\hline Renal & 3 & 1 & 277 & 347 & 257 \\
& & 2 & 551 & 259 & 402 \\
& & 2 & 483 & 258 & 443 \\
& & 3 & 337 & 186 & 289 \\
CNSt & 6 & 1 & 533 & 365 & 607 \\
& & 3 & 388 & 291 & 575 \\
& & 3 & 615 & 328 & 993 \\
& & 4 & 280 & 209 & 490 \\
CNS & 9 & 1 & 491 & 558 & 263 \\
& & 2 & 504 & 458 & 337 \\
& & 2 & 412 & 321 & 179 \\
& & 4 & 416 & 299 & 183 \\
CNS & 10 & 1 & 70 & 94 & 230 \\
& & 2 & 119 & 251 & 300 \\
& & 3 & 70 & 253 & 179 \\
& & 3 & 204 & 166 & 210 \\
Serositis & 19 & 2 & 560 & 256 & 996 \\
& & 2 & 346 & 170 & 890 \\
& & 3 & 402 & 201 & 1112 \\
& & 4 & 286 & 197 & 1064 \\
\hline
\end{tabular}

${ }^{*} A_{495} \times 10^{3}$, all assays at a dilution of 50 times. $+\mathrm{CNS}=$ central nervous system. for each patient we added the disease activity values which pertained at the times at which each of the four blood samples were taken. These estimates of severity (table 1) correlated closely with the levels of IgG and IgA antihistone antibodies $(r=0.655, p<0.001$ for IgG, and $r=0.408, p<0.05$, for IgA; Spearman's rank order test). In contrast, there was no significant correlation between disease activity and IgM antihistone antibody levels $(r=-0 \cdot 147$, $\mathrm{p}>\mathbf{0} \cdot \mathbf{1}$ ).

\section{Discussion}

In analysing the results we considered five factors which may influence levels of antihistone antibodies. These are neither mutually exclusive nor all embracing, but provide a useful framework for discussion.

(1) Disease activity: patients with SLE often have a relapsing-remitting course, and periods of increased disease activity may be associated with changes in antibody levels.

(2) Treatment: administration of drugs, particularly high doses of steroids, may be important.

(3) Individual variation: there may be qualitative and quantitative differences in antibody response mounted by different patients to the same precipitating factors.

(4) Disease type: this may be defined in terms of the organ system primarily affected or by the presence or absence of specific clinical features.

(5) Disease severity: patients differ widely in this respect, some having severe consistently active disease and others generally inactive forms with only occasional relapses. 
In this study we attempted to define the contributions made by some of these factors in determining the levels of antihistone antibodies. In general terms these contributing factors fall into two classes. Factors 1 and 2 all operate at the individual level and would be manifest as differences among serial samples taken over relatively short periods (months rather than years). Factors 3,4 , and 5 will lead to differences among individual patients, but will not make a major contribution to changes in antibody levels in serial samples from any one patient.

Our results show that there is no evidence for a correlation between changes in levels of antihistone antibodies and changes in disease activity in individual patients (table 2). Limited changes in antibody levels, over about a twofold range, did occur with time, a finding consistent with our previous results, ${ }^{17}$ but these changes did not correlate with disease activity at the same time of sampling. More striking changes in antibody levels in serial samples from individual patients have been observed by some workers, and it has been suggested that these may be related to disease activity or steroid treatment, or both, ${ }^{11}$ though the number of patients studied was small. We have not carried out a detailed study of the relation between antihistone antibodies and treatment regimens. The fact that we found little variation among the four samples from each patient, however, suggests that effects related to treatment make only a small contribution to the overall variability in this patient group.

There were no significant differences in levels of antihistone antibodies among the five different clinical subgroups of the disease. Previous studies using solid phase immunoassay techniques have also failed to indicate any significant correlations between clinical variables and the level of antihistone antibodies. ${ }^{11} 1215$ The findings of one study showed significant differences in the prevalence of certain symptoms among patients who did and did not have antihistone antibodies, as detected by an immunofluorescence technique; antibody levels were not measured nor were the isotypes specified. The immunofluorescence technique uses histones in association with cellular DNA and may detect a different antibody population than that detected by solid phase immunoassay.

There was a significant correlation between the levels of antihistone antibodies of the IgG and $\operatorname{IgA}$ isotypes and the severity of the disease, as measured by adding the disease activity scores for each of the four serial samples analysed for each patient. There was no such correlation with IgM antibodies. These findings are consistent with the report of Gioud et al, ${ }^{11}$ who found that an increase in antihistone antibodies (of unidentified isotype) was associated with more active forms of the disease, and with the recent report of Kohda et al, ${ }^{13}$ who found a clear correlation between IgG antihistone antibody levels and the severity of lupus nephritis, measured by the renal histological activity index.

The lack of any correlation between antihistone antibodies and disease activity in indi- vidual patients (table 2) strongly suggests that the high levels of antihistone antibodies in patients with severe disease are not a consequence of disease activity itself. They may instead reflect differences in the aetiology of the mild and severe forms of the disease or individual variation in antibody response (category 3 above). In this case patients who produce high levels of IgG and IgA antihistone antibodies may also be those who are predisposed to develop more severe forms of the disease.

We are grateful to Tim Marshall, department of social medicine; University of Birmingham Medical School, for help with the statistical analysis of our results. This work was supported in part by funds from the Rowbotham Bequest, University of Birmingham Medical School. DAI gratefully acknowledges the support of the Arthritis and Rheumatism Council.

1 Morrow W J W, Isenberg D A. Autoimmune rheumatic disease. Oxford: Blackwell Scientific, 1987.

2 Isenberg D A, Dudeney C, Williams W, Todd-Pokropek W, Stollar B D. Disease activity in systemic lupus erythematosus related to a range of antibodies binding DNA and matosus related to a range of antibodies binding DNA and synthetic

3 Morrow W J W, Isenberg D A, Parry H F, et al. Studies on autoantibodies to poly(ADP-ribose) in SLE and other autoimmune diseases. Ann Rheum Dis 1982; 4: 396-403.

4 Harris E N, Gharavi A E, Booey M L, et al. Anticardiolipin antibodies: detection by radioimmunoassay and association with thrombosis in systemic lupus erythematosus. Lancet 1983; ii: 1211-14.

5 Isenberg D A, Colaço C B, Dudeney C, Todd-Pokropek A, Snaith M L. A study of the relationship between anti-DNA antibody idiotypes and anticardiolipin antibodies with disease activity in systemic lupus erythematosus. Medicine disease activity in systemic lup

6 Maddison P J, Mogavereo H, Provost T T, Reichlin M. The clinical significance of autoantibodies to a soluble cytoplasmic antigen in systemic lupus erythematosus and other connective tissue diseases. $\mathcal{F}$ Rheumatol 1979; 6: 189-95.

7 Scott J S, Massison P J, Taylor D V, Esscher E, Scott O, Skinner R P. Connective tissue disease antibodies to ribonucleoprotein and congenital heart block. $N$ Engl $\mathcal{J}$ Med 1983; 309: 209-12.

8 Stollar B D. Reactions of systemic lupus erythematosus sera with histone fractions and histone-DNA complexes. Arthritis Rheum 1971; 14: 485-92.

9 Fishbein E, Alarcón-Segovia D, Vega J M. Antibodies to histones in systemic lupus erythematosus. Clin Exp Immunol 1979; 36: 145-50.

10 Portanova J P, Rubin R L, Joslin F G, Agnello V D, Tan E M. Reactivity of anti-histone antibodies induced by procainamide and hydralazine. Clin Immunol Immunopathol 1982; 25: 67-79.

11 Gioud M, Ait Kaci M, Monier J C. Histone antibodies in systemic lupus erythematosus. Arthritis Rheum 1982; 25 407-13.

12 Bernstein R M, Hobbs R N, Lea D J, Ward D J, Hughes G R V. Patterns of histone antibodies specificity in systemic rheumatic disease. Arthritis Rheum 1985; 28: 285-93.

13 Kohda S, Kanayama Y, Okamura M, et al. Clinical significance of antibodies to histones in systemic lupus erythecance of antibodies to histones in sys

14 Shoenfeld Y, Segol G, Segol O, et al. Detection of antibodies to total histones and their subfractions in systemic lupus erythematosus patients and their asymptomatic relatives. Arthritis Rheum 1987; 30: 169-75.

15 Krippner H, Springer B, Merle S, Pirlet K. Antibodies to histones of IgG and IgM class in systemic lupus erythematosus. Clin Exp Immunol 1984; 58: 49-56.

16 Fritzler M, Ryan P, Kinsella T D. Clinical features of systemic lupus erythematosus patients with anti-histone antibodies. $\mathcal{F}$ Rheumatol 1982; 9: 46-51.

17 Fellows G, Gittoes N, Scott D G I, Coppock J S, Wainwright A, Goodall M, Turner B M. Individual variation in the isotype profile of anti-histone autoantibodies in systemic isotype profile of anti-histone autoantibodies in systemic
lupus erythematosus. Clin Exp Immunol 1988; 72: 440-5.

18 Tan E M, Cohen A S, Fries J F. The 1982 revised criteria for the classification of systemic lupus erythematosus. Arthritis the classification of system

19 Morrow W J W, Isenberg D A, Todd-Pokropek A, Snaith $M$ L. Laboratory measurements useful in the managemen of systemic lupus erythematosus. $Q \mathcal{F}$ Med 1982; 51 : 125-38.

20 Isenberg D A, Shoenfeld Y, Schwartz R S. Multiple serological reactions and their relationship to clinical activity in systemic lupus erythematosus; a study of 56 patients. Arthritis Rheum 1984; 27: 132-8.

21 Symmons D P M, Coppock J S, Bacon P A. Development and assessment of a computerized index of clinical disease activity in systemic lupus erythematosus. $Q \mathcal{F ~ M e d ~ 1 9 8 8 ; ~}$ 